\title{
The Defensive Strategies of Czech and Ukrainian Residents in the Ukraine against the Effects of the Chernobyl Nuclear Accident
}

\author{
Veronika Beranská - Zdeněk Uherek
}

DOI: 10.21104/CL.2016.1.05

Abstract The text focuses on the theme of health care and amateur treatment in the extreme conditions of increased radiation after the explosion of the nuclear reactor at the Chernobyl power plant. It reconstructs the plight of the population from the accounts of residents living near the Chernobyl power plant, some of whom resettled in the Czech Republic, and analyses the relationship of the new state of affairs for folk healing. The text shows the logic of the adaptation mechanisms of the group of people to the new circumstances and their mobilization of the cognitive potential in the conditions in which professional aid and biomedicine, which they commonly used, failed.

Besides the traditional practices of folk treatment, innovations based on scraps of information gathered from the mass media, reading, knowledge of a healthy lifestyle, the application of extreme medical cures devised by doctors through experimentation, assert themselves under extreme conditions. Other than the information on the application of specific methods and procedures, the text shows the process of how 'human wisdom' on health and disease is formed and adapts to a new, in this case extreme, situation. In an individualized, complex society, these ideas are distinctly private, flexible and situational.
Keywords medical anthropology, Ukraine, Chernobyl region, folk healing.

This study was written with the institutional support of the Institute of Ethnology of the Czech Academy of Sciences, v. v. i., RVO:68378076.

Contact Mgr. Veronika Beranská, Etnologický ústav AV ČR, v. v. i., Na Florenci 3/1420, 11000 Praha 1, Czech Republic; e-mail: veronika.beranska@seznam.cz.

Doc. PhDr. Zdeněk Uherek, CSc., Etnologický ústav AV ČR, v. v. i., Na Florenci 3/1420, 11000 Praha 1, Czech Republic; e-mail: uherek@eu.cas.cz.

Jak citovat / How to cite Beranská, Veronika - Uherek, Zdeněk. (2016). The Defensive Strategies of Czech and Ukrainian Residents in the Ukraine against the Effects of the Chernobyl Nuclear Accident. Český lid 103, 85-101. doi:http:// dx.doi.org/10.21104/CL.2016.1.05 


\section{Introduction}

There is already extensive literature on the issue of the health consequences of the Chernobyl nuclear explosion as one of the largest ecological catastrophes caused by mankind in recent history. It is also well known that, as devastating as the results of the Chernobyl catastrophe were for the human physical organism, they were also uncommonly arduous on the human psyche. For instance, Diana Scott in her text Healing in the Shadow of Chernobyl quotes Holbrook Teter, who conducted social work in the affected areas in the Belarusian contaminated zone. He speaks mainly about the state of hopelessness, loss of perspective and mental apathy (Scott 1996) which accompanies the fear, resulting in sleep disorders, loss of concentration, a general loss of interest, alcoholism and other negative effects (Scott 1996). As we later realized, this state was not only the consequence of devastating physical conditions, but poor awareness or disinformation spread among the population around the Chernobyl power plant, who were kept in ignorance for a long time. The problem of immobility entered this atmosphere. In the conditions of the then Soviet Union, it was not easy to move from the polluted zones. All of these circumstances motivated at least the more active inhabitants of the contaminated areas to try to react to the situation and protect themselves and their family members from the health risks as much as possible.

This text broaches the subject of how the population reacted to the health risks and how they tried to eliminate these risks themselves. We ask what knowledge potential was activated by the inhabitants of the zone and what connection their practices had to 'folk medicine'. We build our findings on the long-term field surveys based mainly on qualitative methods of interview and observation of those who resettled from the areas affected by the Chernobyl nuclear catastrophe to the Czech Republic from 1991 to 1993, and with whom intensive interactions took place from 1991 to 1997. The data collections first took place within more broadly conceived projects; from 1991 to 1993 this was part of a Czech Science Foundation project entitled The Influence of Objective and Subjective Factors on the Transformations of Ethnicity with the Czech Ethnic Groups Abroad (principal investigator Stanislav Brouček) and subsequently from 1994 to 1997 within a project supported by the Czech Science Foundation entitled Processes of the Adaptation and Social Integration of Those Resettled from the Ukraine, Belarus, and Kazakhstan in the Czech Republic (principal investigator Nada Valášková), including field research in the Ukraine in 2000, 2001, 2002 and 2010. The last extensive data collection was implemented within a project supported by the Grant Agency of the Academy of Sciences of the Czech Republic entitled Identity and Sociability of a Migrant from the former Soviet Union: Follow-up research of controlled migration with an emphasis on the second generation, which took place from 2008 to 2011 (principal investigator Zdeněk Uherek). 
The individual projects focused on various aspects of the life of the groups under investigation, and besides observation and interviews, questionnaires were also carried out within its framework. Considering that the investigation primarily focused on the Czech minority in the Ukraine, who partially live in the contaminated zone to this day, our findings can relate mainly to this minority segment of the population and not to the general Ukrainian population in the contaminated area.

In this text we do not examine the results of quantitative collections, but the results of qualitative interviews, recollections of the actors and also observations about their homes and gardens, the cultivation and use of herbs in the Czech Republic and other qualitative data, namely from the entire period over which data was collected, i.e. from 1991 all the way to 2015. The most frequently used data-collection method was the spontaneous unstructured interview, which took place between the authors of the text and the interviewees.

\section{Terminology}

In relation to folk medicine, the term tradition is a relatively complicated label, because it is not clear on a linguistic level. In the Czech context, the term traditional refers to stability, steadiness and permanence, in the Anglo-Saxon sense it refers to originality and uniqueness related to place and individual ethnic groups or cultures. According to the World Health Organization (WHO) 'traditional medicine is the sum total of the knowledge, skills, and practices based on the theories, beliefs, and experiences indigenous to different cultures, whether explicable or not, used in the maintenance of health as well as in the prevention, diagnosis, improvement or treatment of physical and mental illness' (WHO 2014). For those treatment practices which are not components of the local traditions and are not integrated into the dominant system of local medical care, the WHO uses the label complementary/alternative medicine (CAM). The label of folk medicine is used in the common Anglo-Saxon context for both traditional and alternative medicines, and another of its labels is holistic or Eastern. All of these labels are used to separate it from the reigning discourse or Western biomedicine (Western, scientific medicine, biomedicine), which is also labelled as allopathic (Folk Medicine and Traditional Healing, NCFH 2011). It is generally true that in industrial societies the use of complementary medicine is connected with a higher income group and higher education (Eisenberg - Davis - Ettner 1998; Ong - Bodeker 2002), whereas for ethnic minorities in these same societies traditional medicine is often the only choice because of poverty and insufficient linguistic competence, when conventional treatment becomes inaccessible to them. Traditional and complementary treatment, however, is generally on the increase; almost half of the population of many industrialized countries regularly use some form of 
traditional or complementary medicine, for instance the United States $42 \%$, Australia $48 \%$, France $49 \%$, Canada $70 \%$ and a significant number is also recorded in less developed countries: China $40 \%$, Chile $71 \%$, Columbia $40 \%$, and as high as $80 \%$ in African countries (Bodeker - Kronenberg 2002).

Therefore, in this paper, in accordance with the recommendation of the WHO, we use the term folk healing and folk treatment, under which we also include the term traditional, as is common for the Anglo-Saxon context. In order to differentiate the innovative approaches within the defensive practices against radiation, we use the term amateur healing and amateur treatment.

The text is structured into several interlinked segments. In connection with the terminological background, it leads from the introduction to the presentation of several examples of folk healing amongst Czechs in the Ukraine, which illustrate the situation and initial conditions for the emergence of defensive strategies after the nuclear power plant accident. The description of the amateur treatment of the Czech population exposed to radiation is presented here in relation to foreign research.

\section{Context}

The significance of context on people's behaviour, and hence also on their ethnographic studies, has been known for a long time (Shokeid 1992). Now in particular we realize that the context changes the meaning of things and changes their relation to the users to the extent that the subjects could become their components (Strathern 2004). After the nuclear explosion, the situation in the Ukraine was very unclear for local citizens. From the outset there was a complete lack of information, and uncertainty and disorder dominated. Following on from 26 April 1986, when an accident occurred in the fourth block of the Chernobyl nuclear power plant in the Ukraine, the world gradually, and to a limited degree, became aware of the extent of the catastrophe. The then Soviet communist regime withheld information from neighbouring countries as well as from their own citizens near the nuclear power plant. It was not until 1989 that there was a public discussion about the full consequences of the event. The world was kept in the dark for a long time due to the lack of a free flow of information and free movement of people.

The first official report did not come out in the Kiev Evening News until three days after the catastrophe. Soon after the disaster the Soviet authorities evacuated the town of Pripyat, where the power plant was situated, and removed people from a 30-kilometre zone around the power station (Kužel 1997). People at greater distances had to stay in their places of residence without sufficient information about how to protect themselves against the increased radiation or how to obtain suitable aid (Abbott - Wallace - Beck 2006).

However, according to unofficial sources and the testaments of our interviewees, only a few people immediately received information about the 
explosion on the critical day, with more people finding out on the second or third day after the explosion. They were told by relatives, neighbours or coworkers that something had happened. They became aware of the events in the following way. 'A construction worker was working on a building about 40 kilometres from the epicentre of the blast. He saw a flash and smoke and deduced that there had been an accident at Chernobyl.' (female, born 1929, arrival from Mala Zubivczina, Ukraine)' 'A nurse was working in the regional town of Korosten, and on the day of the explosion all the lorries and buses were sent to Chernobyl. The hospital was preparing itself for the admission of patients, and from this the inhabitants deduced that there had been an accident.' (female, born 1938, arrival from Mala Zubivczina, Ukraine) ${ }^{2}$

Similar narratives are also recorded in the literature including the account of an older woman who was sitting on a bench enjoying the sunshine when: 'suddenly a huge armoured vehicle stopped right in front of us. Men wearing gas masks and some kind of protection suit jumped out and started walking around us, looking at the readings on the devices on their chests. Then one of them looked at us and stuck something into the ground which had a strange symbol we had never seen before. They then climbed back into the vehicle and left. All of this happened in complete silence. Not a word had been spoken.' (Scott 1996)

When something dangerous occurs, a person's first reaction is usually to find out more information. Everyone who saw or heard something about the disaster was highly valued at that moment. Our interviewees used to live in the villages of Mala Zubivczina and Malinovka, and in the towns of Malin and Korosten, approximately 60-80 kilometres from the power plant, and they could not confidently hear or see what had happened. In their localities, immediately after the explosion, vague information appeared that someone had heard an explosion. The news gradually leaked out: a part of the power plant had exploded and the air was polluted with radiation.

'We came to know about it after six days... Then the office told us to shut all the windows, wells, everything. Well, we didn't know anything about it. We didn't understand it, and then we found out, they told us, that three firemen had already died there, but other people said that no-one had died. And then, when I was in hospital for an operation, one of those fireman was there too, and he said: "I don't know if I'll be here another week or another year, but I've already had a complete blood transfusion three times, and I don't know how many times they can do it again".' (female, born 1924, arrival from Malinovka, Ukraine) ${ }^{3}$ 
A few days after the explosion, people were officially instructed not to venture outside unless in cases of emergency, and only to eat fruit and vegetables which had been washed by the fresh water which was starting to be supplied from remote areas. In addition to the advice that movement outside be kept to a minimum, it was recommended that the population should limit milk consumption. If milk was to be used, it was to be allowed to stand and its top layer poured off. Consumption of forest fruits and anything growing in the soil was to be avoided, wells were to be covered, children were to be kept inside, and protective measures were to be taken against dust.

However, no-one informed the people about how serious the danger really was. Therefore, people searched for signs of contamination in the environment. They frequently recounted the events on the day of the explosion: they remembered the unusually hot weather, they recalled that, unfortunately, all the town or village inhabitants were outside,

'And one man was telling us...he was an engineer too, he worked there... and he said they had a baby, maybe three months old, and it was terribly hot, so they put the baby on the balcony, and after only a moment it was black, like from some kind of dust.' (female, born 1936, arrival from Malinovka, Ukraine) ${ }^{4}$

'The children close to Chernobyl were sitting in the schools, and it was awful, blood was coming out of their ears and nose, those Chernobyl kids there.' (male, born 1931, arrival from Mala Zubivszina, Ukraine $)^{5}$

'People went on feeling it, because they had scratchy, burning throats and their eyes burned, and people were always tired.' (male, born 1967, arrival from Korosten, Ukraine) ${ }^{6}$

They also recalled that in the following days a lot of big mushrooms appeared in the forest - big mushrooms are frequently mentioned as a direct indicator of radiation. They also recalled that vegetables and fruits were enormously big in 1986, probably due to the radiation,

'and the leaves were turning black and falling off the trees in summer, as if they were burnt' (female, born 1916, arrival from Mala Zubivczina, Ukraine). ${ }^{7}$ 
However, qualified people also lived in the above-mentioned towns and villages. There were physicians, emergency workers and soldiers who were better informed about the effects of increased radiation. They also shared what knowledge they had with their neighbours, as did the local authorities with their instructions and regulations. People pieced this information together with their own experiences and the experiences of their relatives on how to heal their diseases.

Only several years later, people acknowledged that a large quantity of radioactive substances had been released into the atmosphere which contaminated northern Ukraine as far as Kiev, western Russia, and southern and eastern Belarus. In this area, radioactivity levels remain a dozen times higher than normal and are likely to do so far around 300 years (Metivier 2002). On several occasions, therefore, our interviewees' testimonies became indictments of the authorities who had failed to inform the locality:

'On the First of May there were still processions everywhere, everybody, the schools, the children outside and no one said anything. ${ }^{8}$

'When they were fighting the blaze at the reactor, and foam was coming out of it, when the reactor was burning, the children, the children were playing in the foam, splashing themselves in it as if nothing was happening.' (male, born 1931, arrival from Mala Zubivczina, Ukraine $)^{9}$

\section{Actors}

As mentioned above, most of our interviewees lived about 60-80 kilometres from the Chernobyl power plant at the time of disaster. In the 1990s, most of them settled in the Czech Republic for three main reasons:

1. for economic reasons (they work here);

2. for social reasons (they rejoined their families in the Czech Republic);

3. for health reasons.

At the start of the 1990s the largest group of people leaving the Ukraine for the Czech Republic for health reasons numbered around 2,000 people, who dispersed around the Czech Republic. This was termed an ecological migration by, among others, the British sociologist Claire Wallace (Wallace - Stola 2001). The Ministry of the Interior ensured the group could move into renovated flats and helped at least one member per family find work, which nevertheless did 
not correspond to their qualifications (Valášková - Uherek - Brouček 1997; Uherek 2009; Uherek - Beranská 2015).

The people who were interviewed in the Ukraine were predominantly relatives of those from the Czech Republic. They remained in the contaminated areas either due to family reasons or due to their inability to follow their relatives during the guided migrations from 1991 to 1993 - a period when the government helped migrants and provided them with accommodation and a job for at least one family member. Later on, when the Czech state assistance was halted, moving from the contaminated area became difficult for them. ${ }^{10}$

\section{Preconditions for forming healing defensive strategies}

Although many of our actors came from a rural background, the majority had non-agricultural occupations, and there were secondary-school and university-educated people among them. Life in a socialist state had influenced their thinking. Since 1917 our subjects and their ancestors had lived in the Soviet socialist environment and had been provided with a state and institutionalized health care that did not tolerate alternative healing methods. Folk healing was prohibited as was connecting health care with paganism. It is also necessary to mention that any description of Ukrainian 'traditional' medicine is in itself somewhat problematic, because as with other medical traditions it has borrowed and mixed influences, and in this case it was also suppressed, forcibly Russified from the 1930s and incorporated into the overall structure of Soviet medicine (Hanitkevych 2005). Nevertheless, the local knowledge of phytotherapy survived the entire communist period and we have recorded several areas in human health where folk healing has been applied. ${ }^{11}$

The treatment of the Czechs who resettled from the Ukraine is characteristic, particularly for its syncretism, which lies in the merging of the original knowledge from the Czech lands of the second half of the 19th century with the new methods and knowledge from the Ukraine. There is a similar situation with the Ukrainians, for example with Ukrainian immigrants who resettled in Canada (around Alberta, Manitoba etc.) and predominantly used domestic cures for the entire 19th century at their remote agricultural homesteads, and passed down the medical formulas from generation to generation (Mucz 2012; Klymasz 1989). They were also influenced by the breadth of knowledge acquired in the host countries and gradually changed and adapted

10 Houses here are unsaleable and savings were usually insufficient for assuring a respectable life in the Czech Republic. Moreover, the Ukrainian government provides extra payments to stabilize the population in the contaminated zone; the population here calls it death allowance, which increases the living standard of the residents here and discourages them from moving away. 
to the conditions in their new environment. The various methods and recipes which were described by the Czechs who resettled from the Ukraine can also be observed in practice.

The Czechs in the Ukraine used folk healing for common problems such as colds, slight viral infections, burns or scratches of the skin, fatigue (exhaustion), headaches, stomach troubles etc. Our respondents spoke about the use of Pot marigold (Calendula officinalis) for swollen legs: 'I collect the marigold in the small garden... and then I make that lotion and spread it on those painful feet.' (female, born 1939, arrival from Mala Zubivczina, Ukraine), ${ }^{12}$ Common nettle (Urtica dioica) for kidney disease: 'I dry those here at the window. I have them for the kidneys... I get them from behind the house...' (female, born 1940, arrival from Malinovka, Ukraine), ${ }^{13}$ a mixture of pepper, honey and spirits for a cold:

'I know such a recipe, you just reminded me... I take 1 dcl of vodka and a teaspoon of ground pepper...then I run a tub full of hot water and the flu comes out of the pores as the person sweats, then they climb into bed and sweat it out. In the morning, the person is completely healthy. He has to have a healthy heart though... Then I know another one for a cold... We take rosehip syrup, a teaspoon of honey and cognac, you can also add lemon juice and it is good for a cold and the immunity...' (male, born 1946, arrival from Mala Zubivczina, Ukraine). ${ }^{14}$

Another example of folk healing is the use of white lily (Lilium candidum) in a spirit for germicide and back pain, Rye (Secale cereale) for diabetes mellitus: 'My husband brought rye from the Ukraine for diabetes -, he read somewhere that it is good... He simmers the rye and then drinks this liquid broth. He read it somewhere so he tried it...' (female, born 1951, arrival from Mala Zubivczina, Ukraine), ${ }^{15}$ Sea buckthorn (Hippophae rhamnoides) for a cold, cough or skin lesions etc. An important role was also played by folk-medicine healers in the Ukraine who were contacted especially for the treatment of warts and unusual lumps under the skin (Stickley - Koyanagi - Richardson - Roberts Balabanova - McKee 2013).

Another area of folk medicine in the Ukraine, recorded from the testimonies of the Czechs who resettled, contains elements of folk sympathetic (homeopathic) magic with onomatopoeic enchantment. This area shows archaic elements of popular folklore and was a living tradition in the Ukraine until the end of the 20th century (Phillips 2004). It was still being documented in

12 Interview 3. 10. 2010 in Rokytnice v Orlických horách, district Rychnov n. Kněžnou, East Bohemia.

13 Interview 9. 8. 2009 in Kuřivody, district Česká Lípa, North Bohemia.

14 Interview 8. 10. 2011 in Jaroměř-Josefov, district Náchod, North Bohemia.

15 Interview 8. 10. 2011 in Jaroměř-Josefov, district Náchod, North Bohemia. 
the Czech Republic for, among other things, the treatment of consumption (tuberculosis) up until the middle of the 20th century (Polák 1943).

Another example we can mention was for the treatment of the painful bacterial dermal enterococcal disease erysipelas or Saint Anthony's fire (in Czech 'the rose'), using a mixture of dried and powdered rose petals, camomile and flax while whispering a prayer above the heat and the smouldering fire:

'She took camomile, flax and collected rose petals... Then she broke the stubble of the flax like this. She mixes it. She lights wood, peat (Do you know what that is? ... Well, it is on the river bottom. From peatmoss the peat is cut into squares and then used for burning). So she sprinkled camomile and, rose petals onto the coal and she warmed herself above that and whispered... And believe it or not, it helped.' (female, born 1940, arrival from Mala Zubivczina, Ukraine, memories of her grandmother, a healer, named Anastasia Rybova (ca 1895-1959) from Mala Zubivczina). ${ }^{16}$

The ritualized forms of treatment were recorded particularly in diseases caused by bewitching, the so-called evil eye, or in the above-mentioned disease called consumption, which is characterized by tiredness, weariness, yawning and overall exhaustion (for more, see Beranská 2013; Kindl 2010). With these ritual practices, the level of syncretism cannot be determined either, because these ritual practices and bewitching appeared independently of one another both in the Czech lands and in the Ukraine. In this regard, a comparison again with the Ukrainian (and in many ways also Czech) immigrants is interesting, though this time with those who settled in Kazakhstan. They left the Czech lands for the Ukraine, Moldova and then for Kazakhstan approximately at the same time as the Ukrainian migration wave heading for Canada. Although their folklore and cultural practices are similar to Ukrainian practices in the Ukraine, Canada and Bohemia, they understandably differ in their adaptation to the new environment.

In Canada, Ukrainians preserved their medical methods adopted from the Ukraine, but they removed the attributes of ritual practices and a magical vision of the world, in accordance with social convention in Canada (Kononenko 2011). In Kazakhstan, on the other hand, the magical view of the world was preserved both by Czech immigrants (Uherek et al. 2003) and Ukrainian immigrants, where, moreover, it was strengthened due to the harsh living conditions (Kononenko 2011).

The examples mentioned above show a great deal of variability as well as the independence of the Czech population in the Ukraine in terms of selfhealing practices, and they show the creativity and invention in their ideas, 
which after the accident at the Chernobyl nuclear power plant resulted in the first aid against radiation and its after effects.

\section{The role of folk medicine and healing practices after the Chernobyl nuclear catastrophe}

Ulrich Beck noted that Chernobyl was an 'anthropological shock' in Western Europe. The shock came primarily from the fact that everyday knowledge proved useless in the face of this catastrophe, as did expert knowledge (Beck 1987: 153-65). Radiation was ever-present and ideas about where the danger was less differed between people. Some believed that the greatest danger was in the air, others that everything had been absorbed by the soil. The logical and relatively simple defensive strategy was to change eating patterns. Yet there was no universal acceptance of the recommendations being disseminated by the authorities (Abbott - Wallace - Beck 2006). Gradually some staple foods were imported to the contaminated area, nevertheless they were expensive: 'And as for it being in the ground [radioactivity - Z. U.] ..., they still went as far as Dombasa, a thousand kilometres, where there weren't any potatoes, and took them there.' (male, born 1931, arrival from Mala Zubivczina) ${ }^{17}$

Therefore, many people from the contaminated area were eventually resigned to doing nothing for their health: 'And then they came and gave us advice, for example not to drink milk, but what were we going to drink, we have our own ways.' (male, born 1924, arrival from Malin) ${ }^{18}$

To accept the official propaganda on how to protect their health, there was some mention of how to accept the new conditions for living in the contaminated zone. Any refusal of these new hygienic rules could be also interpreted as a type of protest. As Anne Keane realistically noticed: 'Food and power are everywhere intimately linked ... Because 'healthy eating is clearly a political issue' in post-Chernobyl Ukraine, as in other parts of the world (Keane 1997: 179), Ukrainians frequently bought rather cheaper food without a label 'radiation control guaranteed' than spend a lot of money elsewhere. They replied, 'Should I die because of hunger? It is better to die of radiation than to die of hunger..."19 (Abbott - Wallace - Beck 2006: 115)

However, there were a lot of people who adapted some of the folk-healing methods to the situation after the radiation. For example, the use of potatoes or raw uncooked eggs for enlarged lymphatic nodes. The use of eggs was already present in the Ukraine before the nuclear disaster; eggs were used for diagnosis and treatment, particularly in the central part of the country, where it became analogous to the wax ritual in western parts of the Ukraine (Phillips

17 Interview 14. 7.1992 in Butoves, district Jičín, East Bohemia.

18 Interview 28. 11. 1993 in Stráž pod Ralskem, district Česká Lípa, North Bohemia.

19 Female respondent from the Ukraine. 
2004). In the Czech Republic we recorded raw eggs being used in the treatment of enlarged lymphatic glands with a respondent from Mala Zubivczina (male, born 1946, arrival from Mala Zubivczina, Ukraine):

'And after Chernobyl one nephew had enlarged glands on his neck... and I saw how grandmother took raw eggs and rolled them on his neck and whispered a prayer... and it helped, it really helped... the egg might have something that draws it out that way... ${ }^{20}$

The process of filtration acquired great importance as well. People were instructed that the radioactivity was in the milk, water, fruit and vegetables. Radioactivity is not visible but peoples' experience is that polluted liquids can be purified by filtration. Thus some families developed a method how to filtrate the milk through a loaf of bread. According to some other families, everything that was grown on the surface seemed dangerous for them, while what was cultivated underground was perceived as relatively safe.

Another case was the process of filtration through the digestive tract of domestic animals. Some immigrants believed that if something had passed through the digestive tract of domestic animals, then it had been more or less purified. Therefore, the meat of a cow was perceived as relatively radiationfree or better than, for instance, water which had absorbed the radiation from the contaminated environment. Nevertheless, the above notions were not socially codified. Every single family had different opinions. For instance, some families considered milk from domestic sources to be relatively free of radiation, while others did not.

Some of the residents tried to keep healthy by purchasing low-cost foods that they conceptualized as 'radioprotectors' - foods as a 'sorbent' - latching onto radionuclides in the organism and removing them from the body (Phillips 2002: 9). For example, Vitamins C, A, and E, beta-carotene, pectins, iodine, and folic acid were considered to be radioprotectors (for example salads with vitamin-rich canned seaweed, apples containing pectin, carrots and orange vegetables due to carotene) (Phillips 2002: 8). However, the authorities did not recommended consuming products from gardens and estates in the contaminated zone, despite the fact that the local economy of families was based on cheap domestic production.

An alternative reaction to the contaminated milieu was to eat nothing at all. Some residents set out on this path and wagered on the treatment of A. I. Vorobyev, a Russian academic, when they underwent long-term treatment by fasting, which reputedly would ensure the elimination of radionuclides from the organism. Others then followed Valery Yerofeyev, who recommended in 
the first stage a 21-day fast, and in the second stage the consumption of radioprotective sources, where he mostly recommended linseed, liquors and juices from herbs, infusions from blueberries and even copper. He recommended a diet which was similar to the diet for cancer patients. He summarized his recommendations along with other historical discussions on folk medicine, such as his descriptions of cures with worms or leeches, in the publication Unique Methods of Folk Healers (Jerofejev 2003).

Naturally, there were large groups of people who gave up on any kind of prevention. The sense of demoralization was paradoxically increased by the system of financial compensation for people living close to the power plant. The benefit, labelled a 'death allowance' by the local population, enabled a modest living at the state's expense, and people could therefore stop working. This Ukrainian compensation system was criticized by the Russians and Belarusians who saw it as a 'struggle for power and material resources related to the disaster' (Petryna 2004). Surprisingly, the death allowance did not increase the rate of migration from the contaminated area. Many people became dependent on the allowances and the financial compensation, which kept them attached to the area. There were even cases of people moving from slightly polluted areas to the contaminated zone in anticipation of the death allowance.

\section{Conclusion}

Chernobyl in 1986 is a dramatic example of the type of incidents that are characteristic of a 'risk society' (Abbott - Wallace - Beck 2006). According to Abbott, Wallace, Beck (2006), the suffering of the people living nearby has been compounded by the economic collapse that followed the disintegration of the USSR in 1991, leaving them in what Rinkevicius (2000) has called 'double risk societies'. Chernobyl was associated with the collapse of Soviet life in general (Petryna 2004). It was definitely a key political event with many consequences, some of which are still unknown; some of which will remain unknown. According to Adriana Petryna, the Ukraine became the most significant place to examine the relations between risk, rational-technical power, and the emergence of a new population called poterpili (sufferers), who numbered 3.5 million and constituted 7 percent of the Ukrainian population (political economy of illness) (Petryna 2004).

The strategies through which people deal with health risks reflect the society in which the healing takes place. The state did not generate a collectively acceptable strategy and so every family created its own, which it also justified 'rationally' and independently. This tended to be based on private knowledge, facts, memories and other types of information, which resulted in methods which were sometimes not so different from magical practices. Similar traits also acquired healing practices used against radioactivity in Ural village Muslumovo which studied Galina Komarova (Komarovová: 1997). In 
the vicinity of the Chernobyl power plant, the healing methods were not subject to any collective codification by the villages, the Czech minority or the wider society. They have remained on the level of personal or familial experiments, just as with other behaviour in a fragmented, incoherent society. In the end, for many actors a collectively accepted and widely applied strategy only appeared with emigration from the contaminated zone.

However, as was shown by the recent tragic accident at another nuclear power plant in Japan in March 2011, the political climate and collapse of the existing structures do not always have such an influence on the effect of the event. After an earthquake and the subsequent tsunami in the Tohoku region and the Fukushima Prefecture, which caused the meltdown of the overheated core of the nuclear reactor at the Fukushima Daiichi nuclear power plant, the situation which followed was not dissimilar to that in Chernobyl, the Ukraine in 1986. Although it is an imperial island state in East Asia with an entirely different ruling grouping, political apparatus and different economic base than in the former Soviet Bloc, the subsequent events showed a number of similarities. The majority of the world's population today might expect more contrasts than parallels with the nuclear accident in Chernobyl in 1986, as was also highlighted by Sarah Phillips, who interviewed survivors of the atomic disaster in the Ukraine and in Fukushima (Phillips 2013). People were living with risk and uncertainty and in the literature we encounter the analogy of life with chronic illnesses (Abbott - Wallace - Beck 2006; Bury 1982). People with distinctive psychological and emotional stress in Fukushima could also be diagnosed with so-called radiophobia by experts (Petryna 2002). Fear, posttraumatic stress syndrome and other mental disorders became characteristic features of the post-radiation situation in Chernobyl as well as Fukushima (Petryna 2002; Brumfiel 2013).

As is clear from the contributions mentioned above, after the Chernobyl catastrophe people were dependent mainly on themselves and their knowledge, which they had to use, adapt and modify to the constantly changing situation. Natural healing, which predominantly drew from folk tradition and was a fixed collection of methods and practices to recover from common nonlife-threatening diseases, became a purely utilitarian activity with modes and means which were adapted to different situations, where people had no other alternative of how to help themselves. Therefore, tradition mixed with other aspects of individual experience became a living eclectic alternative with a purely utilitarian focus.

The mutability of folk medicine is a relatively common feature, although the frequent label of 'traditional' implies permanence. Typologically, the dynamic of the transformations can differ. For instance, this can be the mutability in relation to the place of its activity, i.e. due to the movement of the people who carry out these practices. It is clear, for example, with the forementioned 
Ukrainian immigrants in Canada, where they gradually adapted the healing practices brought from their homeland to the resources which were available locally (Mucz 2012: 15). However, the core of their medical practices, which form the base of folk medicine, remained intact (Mucz 2012; Klymasz 1989). On the other hand, with healing in Chernobyl the transformation was caused by the change in living conditions, which happened in the actors' own environment, and the motivation for dynamic transformation was the change to the environment and primarily fear for their lives, which is a much more significant motivational stimulus for innovative behaviour.

Today those who resettled to the Czech Republic have been out of this contaminated region for more than 20 years. Nevertheless, they still use some healing practices, and there are even some people who do business in the contaminated environment, providing goods which could reduce the effects of the radiation (for more, see Uherek - Beranská 2015).

\section{February 2016}

\section{References}

Abbott, Pamela - Wallace, Claire - Beck, Matthias. 2006. Chernobyl: Living with risk and uncertainty. Health, Risk \& Society 8, 2: 105-121.

Beck, Ulrich. 1987. The Anthropological shock: Chernobyl and the contours of a risk society. Berkeley Journal of Sociology 32: 153-165.

Beranská, Veronika. 2013. Krajanská lidová léčba a ritualizované praktiky u Čechů z Ukrajiny a Kazachstánu přesídlených do České republiky. Národopisná revue 23, 4: 264-271.

Bodeker, Gerard - Kronenberg, Fredi. 2002. A Public Health Agenda for Traditional, Complementary, and Alternative Medicine. American Journal of Public Health 92, 10: 1582-1591.

Brumfiel, Geoff. 2013. Fukushima: Fallout of Fear. Nature. International Weekly Journal of Science 493, 7432. [2015-11-28] Retrieved from: http://www.nature.com/ news/fukushima-fallout-of-fear-1.12194.

Bury, Michael. 1982. Chronic illness as a biographical disruption. Sociology of Health and IIIness 4: 167-182.
Eisenberg, David M. - Davis, Roger B. Ettner, Susan L. et al. 1998. Trends in alternative medicine use in the United States, 1990-1997: results of a follow-up national survey. JAMA 280: 1569-1575.

Folk Medicine and Traditional Healing. 2011. National Center for Farmworker Health. [2016-02-16] Retrieved from: http://www. ncfh.org/uploads/3/8/6/8/38685499/ fs-folk_medicine.pdf.

Hanitkevych, Yaroslav. 2005. The History of Ukrainian Medicine. Vesalius XI, 11: 104-106.

Jerofejev, Valerij. 2003. Unikátní metody lidových léčitelů. Eko-konzult.

Keane, Anne. 1997. Too hard to swallow? The palatability of healthy eating advice. In: Caplan, Pat (ed.): Food, Health and Identity. London and New York: Routledge: 172-192.

Kindl, Josef. 2010. O nemocech, stonání a léčení na Volyni. Sdružení Čechů z Volyně a jejich přátel 3.

Klymasz, Andrea K. 1989. Ukrainian Folk Medicine in Canada. Material Culture Review/Revue de la culture matérielle, vol. 29. [2015-09-24] Retrieved from: 
https://journals.lib.unb.ca/index.php/ MCR/article/view/17400/22612.

Komarovová, Galina. 1997. Uralský „Černobyl“ a problémy etnoekologické adaptace. Český lid 84: 29-38.

Kononenko, Natalie. 2011.

Ukrainian Folklore in Kazakhstan. Folklorica XVI: 163-183.

Kužel, Stanislav. 1997. Lidé v bývalé druhé zóně. Český lid 84: 191-200.

Metivier, Henri. 2002.- Chernobyl: Assessment of radiological and health impact: 2002 Update of Chernobyl 10 years on. Paris: OECDNEA.

Mucz, Michael. 2012. Baba's Kitchen Medicines. Folk Remedies of Ukrainian Settlers in Western Canada. The University of Alberta Press.

Ong, Chi-Keong - Bodeker, Gerard C. 2002. Use of complementary and alternative medicine services in England. American Journal of Public Health 92: 1653-1656.

Phillips, Sarah Drue. 2002. Half-Lives and Healthy Bodies: Discourses on 'contaminated' food and healing in post-Chernobyl Ukraine. Food \& Foodways 10: 1-27.

Phillips, Sarah Drue. 2004. Waxing Like the Moon: Women Folk Healers in Rural Western Ukraine. Folklorica IX: 13-45.

Phillips, Sarah Drue. 2013. Fukushima is not Chernobyl? Don't be so sure. Somatosphere, March 11. [2015-01-21] Retrieved from: http://somatosphere. net/2013/03/fukushima-is-notchernobyl-dont-be-so-sure.html.

Petryna, Adriana. 2002. Life Exposed: Biological Citizens after Chernobyl. Princeton: Princeton University Press.

Petryna, Adriana. 2004. The science and politics of Chernobyl-exposed populations. In: Good, Byron J. (ed.) et al. 2010: A Reader in medical anthropology. Theoretical trajectories, emergent realities. USA: Wiley-Blackwell: 199-212.

Polák, Josef. 1943. Mze (stírat mze). Naše řeč 27, 3. Ústav pro jazyk český Akademie věd ČR, v. v. i. [2015-08-13] Retrieved from: http://nase-rec. ujc.cas.cz/archiv.php?art=3751.
Rinkevicius, Leonardas. 2000. Public risk perceptions in a 'double risk' society: The case of the Ignaline Nuclear Power Plant Lithuania. Innovation: The European Journal of Social Science Research 13: 279-289.

Scott, Diana. 1996. Healing in the Shadow of Chernobyl. Albion Monitor, May 5. [2016-01-11] Retrieved from: http://www.albionmonitor.com/55-96/chernobylshadow.html.

Shokeid, Moshe. 1992. Commitment and Contextual Study. Cultural Anthropology 7, 4: 464-477.

Stickley, Andrew - Koyanagi, Ai Richardson, Erica - Roberts, Bayard Balabanova, Dina - McKee, Martin. 2013. Prevalence and factors associated with the use of alternative (folk) medicine practitioners in 8 countries of the former Soviet Union. Biomedcentral Complementary and Alternative Medicine 13: 83. [2016-01-20]

Retrieved from: http://www. biomedcentral.com/1472-6882/13/83.

Strathern, Marilyn. 2004. Partial Connection. Oxford: Altamira Press. 2. Edition.

Uherek, Zdeněk et al. 2003. Češi z Kazachstánu a jejich přesídlení do České republiky. Praha: Etnologický ústav AV ČR, v. v. i. Uherek, Zdeněk. 2009. Immigrants from the Ukraine in the Czech Republic: Foreigners in the Border Zone. In: Kürti, Laszlo - Skalník, Petr (eds.): Postsocialist Europe: Anthropological Perspective from Home. New York: Berghahn: 270-294.

Uherek, Zdeněk - Beranská, Veronika. 2015. Pavlivka Iodine Spring Water: Transnational Entrepreneurship in Post-Transition Contexts. In: Červinková, Hana - Buchowski, Michał Uherek, Zdeněk (eds.): Rethinking Ethnography in Central Europe. New York: Palgrave Macmillan: 75-88. Valášková, Nad'a - Uherek, Zdeněk Brouček, Stanislav. 1997. Aliens or One's Own People: Czech Immigrants from the Ukraine in the Czech Republic. Praha: Institute of Ethnology of the Academy of Sciences of the Czech Republic. 
Wallace, Claire - Stola, Dariusz. 2001.

Patterns of Migration in Central Europe.

Houndmills, New York: Palgrave.

[WHO] Traditional Medicine: Definitions.

World Health Organization. [2016-01-12]

Retrieved from: http://www.

who.int/medicines/areas/

traditional/definitions/en/. 
